\title{
5 \\ The Neoliberal Rationality of Voluntary Assisted Dying
}

\author{
Marc Trabsky
}

In the first volume of The History of Sexuality, Michel Foucault traces a shift in the eighteenth century from the sovereign's 'right to decide life and death' towards a 'power of life and death'. ${ }^{1}$ The latter was more concerned with techniques for managing life, maximising its efficacy and exploiting its vitality, evinced by a governmental preoccupation with monitoring fluctuations in birth and death rates. Foucault calls this new relation of power-knowledge 'biopower', which consisted of an anatomo-politics of the body and a bio-politics of the population. ${ }^{2}$ The regulation of death, including its control by the state and a range of medical, legal and financial institutions, also gave rise to a new arrangement of thanato-politics, or the government of death. ${ }^{3}$ For Foucault, government does not simply refer to an institution, but to a historical practice that had as its ultimate aim the care of a population. In the nineteenth century, the art of governing developed a range of techniques for managing populations of the dying. ${ }^{4}$

\footnotetext{
1 Michel Foucault, The History of Sexuality, Volume 1: The Will to Knowledge, tr Robert Hurley (Penguin Books, 1998) 136.

2 Ibid 139.

3 Michel Foucault, 'The Political Technology of Individuals' in Luther H Martin, Huck Gutman and Patrick H Hutton (eds), Technologies of the Self: A Seminar with Michel Foucault (University of Massachusetts Press, 1st ed, 1988) 160.

4 See further, Marc Trabsky, Law and the Dead: Technology, Relations and Institutions (Routledge, 2019), which writes an institutional history of the dead that pays attention to questions of technology, jurisdiction and office. The book emphasises the importance of conceptualising law as a network of institutions, relations and technologies when examining how coroners encountered the dead in the nineteenth and twentieth centuries.
} 
The Voluntary Assisted Dying Act 2017 (Vic) provides an opportunity to reflect upon the transformations of the government of death in the twenty-first century. In 'The Political Technology of Individuals', Foucault recounts how 'caring' for individual life emerged as 'a duty for the state' in the eighteenth century. ${ }^{5}$ In the nineteenth century, the medicalisation of the deathbed framed 'care for the dying' as an object of state governance. 'The medical hastening of death', Shai Lavi writes, 'became a last resort to the problem of dying, a limited hope of mastery in the face of a hopeless condition.' ${ }^{6}$ This chapter conceives of 'voluntary assisted dying' as a legal technology, that is, not simply a political or medical technology, but a jurisdictional device that cultivates legal relations between, and holds together, the living, the dying and the state. It describes the legislative framework that authorises voluntary assisted dying as part of a repertoire of governmental practices that tether the dying to law in the twenty-first century. The chapter thus invites readers to approach law in terms of the materiality of its institutions, the technologies that congeal around institutional practices and the performances of different roles that sustain the vitality of legal institutions.

When examining the institutional practices of caring for the dying, the concept of technology should not be limited to lethal medication or lifesupporting machinery that sustain life or hasten death. The term finds its etymological roots in the Ancient Greek word for technique (technê), which denotes a skill, art or craft. Technê was conceptualised by Aristotle as 'craft-knowledge', or rather "'productive knowledge", [which] bears upon the domain of what is mutable, in the process of becoming, and comes to be'. If technology is a tool or instrument that is capable of constructing meaning, then in managing populations of the dying, it includes the provision of legal advice and the application of statutory interpretation, operational manuals and guidance notes, record-keeping and form-filling, and an array of bureaucratic procedures for determining whether an individual can lawfully self-administer or access medical assistance for hastening their death. The 'Easy Booklet' released by the Victorian Department of Health and Human Services in 2018 to communicate to a pluralised audience the complexity of the legislative

\footnotetext{
$5 \quad$ Foucault (n 4) 147.

6 Shai Lavi, 'How Dying Became a "Life Crisis"' (2008) 137(1) Dadalus 57, 64.

7 Wolfgang Schadewaldt, 'The Greek Concepts of "Nature" and "Technique”' in Robert C Scharff and Val Pusek (eds), Philosophy of Technology: The Technological Condition: An Anthology (John Wiley \& Sons, Inc, 2nd ed, 2014).
} 
framework of voluntary assisted dying is not only a legal technology in itself, but consists of a number of visual and textual signs and devices for attaching the dying to the institutional life of law.

In Jurisdiction, Shaunnagh Dorsett and Shaun McVeigh consider the Rights of the Terminally Ill Act 1995 (NT), which was nullified by the Euthanasia Laws Act 1997 (Cth), through the theoretical framework of a jurisdiction of persons. The legislative agenda in the Northern Territory, which temporarily rendered euthanasia lawful in Australia, created a new kind of person, the terminally ill, and a new type of jurisdiction, which lay between conscience and government. The person of the terminally ill arranged, according to Dorsett and McVeigh, new legal relations between the doctor and the patient for caring for the dying, while the creation of the jurisdiction of 'lawful killing', which also reshaped legal relations between the doctor and the state, suspended the operation of the criminal law. The Rights of the Terminally Ill Act functioned as a 'state-centred ars moriendi $i^{8}$, an institutional manual instructing individuals on how to prepare for their medically supervised death:
What is established through the array of procedural, administrative and classificatory devices is an ars moriendi or preparation for death, that can be phrased in terms of an ethic and practice of civility, particularly social honour, suitable for medically assisted suicide and euthanasia. It can also be phrased in terms of a government project. ${ }^{9}$

This chapter examines an important aspect of the government project of taking care of the dying that is missing from Dorsett and McVeigh's analysis of the temporary legalisation of euthanasia in the Northern Territory. It considers how the discourse of neoliberal rationality is a vital component of the implementation of a voluntary assisted dying regime in Victoria. The chapter will focus on how legal technologies for taking care of the dying form part of a repertoire of governmental practices that economise relations between the living, the dying and the state. In Undoing the Demos: Neoliberalism's Stealth Revolution, Wendy Brown argues that ' $[\mathrm{w}]$ idespread economization of heretofore noneconomic domains, activities, and subjects, but not necessarily marketization or monetization of them, then is the distinctive signature of neoliberal

8 Shaun McVeigh, 'Subjects of Jurisdiction: The Dying, Northern Territory, Australia, 1995-1997' in Shaun McVeigh (ed), Jurisprudence of Jurisdiction (Routledge, 2007) 206.

9 Shaunnagh Dorsett and Shaun McVeigh, Jurisdiction (Routledge, 2012) 87 (emphasis added). 
rationality. ${ }^{10}$ In other words, neoliberalism is no longer simply defined by the accumulation of capital through exchange, cost-benefit analysis or entrepreneurialism, which are nonetheless still valued in the art of government. Rather, its distinctiveness lies in how it extends techniques of economisation - the creation of what Foucault calls ' homo oeconomicus' ${ }^{11}$ - into areas of life that were once thought of as non-economic. This chapter then questions how voluntary assisted dying is economised under neoliberalism, and how the dying themselves participate as 'decisionmakers' in an economy of human capital.

The economisation of dying in the twenty-first century has been marginalised in critical responses to the legalisation of voluntary assisted dying around the world. This chapter aims to account for how the figure of homo oeconomicus extends into spheres of dying, but also what the effects of neoliberal rationality are for understanding transformations in the government of death in the twenty-first century. I will contend that first, it is important that we recognise how the language of economisation suffuses legal relations between decision-makers, medical practitioners and the state, and second, we need to examine how an economy of human capital, as a model for the conduct of government, but also the government of self, will lead to differential experiences of voluntary assisted dying. The problem of access to the administrative procedures for assisted dying is not separable from the raison d'être of neoliberalism, such as the replacement of exchange with competition, the substitution of labour with human capital and the augmentation of socio-economic inequality.

\section{Dying as a matter of choice}

In writing a history of euthanasia in the United States, Shai Lavi locates the genesis of discourse about medically hastening death in the nineteenth century, not the twentieth century. The medicalisation of the deathbed, which was shaped by the assumption of a 'duty to provide care in the absence of any possible cure', foreshadowed the doctor's usurpation of the traditional role assumed by the clergy in taking care of the dying. ${ }^{12}$

10 Wendy Brown, Undoing the Demos: Neoliberalism's Stealth Revolution (Zone Books, 2015) 31-2.

11 Michel Foucault, The Birth of Biopolitics: Lectures at the College de France 1978-1979, tr Graham Burchell, ed Arnold I Davidson (Picador, 2008).

12 Lavi (n 7) 61. See further, Shai J Lavi, The Modern Art of Dying: A History of Euthanasia in the United States (Princeton University Press, 2005). 
The patient's cries of moribund suffering were no longer met with prayers, but posed a medical quandary that only a doctor could master. In debates from at least the 1870 s, euthanasia emerged as a possible medical 'choice' among a limited range of options for the dying patient. What thus appeared in the late nineteenth century was that the manner of dying could become a matter of choice, liberty and autonomy.

The nineteenth-century ideal of an autonomous patient, who could decide whether to accept or refuse futile medical treatment, prefigured the emergence in the twentieth century of the consumer patient, where alongside the support of a discourse of right, the manner of dying became a commodified object. Medical advancements in the second half of the twentieth century extended life to such an extent that taking care of the dying materialised as an economic problem for medical, legal, financial and governmental institutions. ${ }^{13}$ The invention of medication, machinery and surgical methods and treatments, to extend, sustain and support life, undoubtedly resulted in human beings living longer. However, they were only living longer because of the support of costly instruments and apparatuses as well as labour-intensive human resources. The technical mastery sought by doctors and longed for by patients about the time, place and quality of dying became increasingly contingent on the question of economic rationality. This is of course part of a repertoire of institutional practices that have sought to economise many aspects of death, ranging from health, life and funeral insurance, methods of disposal of human remains, management of estates and the transgenerational life of debt, production of mortality statistics and classification tables, public and private systems of registration and certification, delivery of social, psychological and spiritual services for the bereaved, and the provision of medical and legal advice for the dying. ${ }^{14}$

The question of where, when and how one dies is routinely subject to economic analysis in the twenty-first century. Hal Swerissen and Stephen Duckett from the Grattan Institute published a report in 2014 showing that while 60 to 70 per cent of Australians prefer to die in the comfort of their home, in reality 54 per cent die in hospitals and 34 per cent in

13 Lavi (n 7) 59.

14 On the link between the compilation of mortality statistics and the emergence of an insurance industry that accumulates profits by financialising the timing of death, see Zohreh Bayatrizi, 'From Fate to Risk: The Quantification of Mortality in Early Modern Statistics' (2008) 25(1) Theory, Culture and Society 121. 
residential care. ${ }^{15}$ The main reason for this discrepancy between 'demand and supply' is a lack of public funding for community-based palliative care services, and as they warn, 'the costs of dying are likely to increase dramatically in the near future as more people die each year'. ${ }^{16}$ On the other hand, The Economist ranked Australia as offering the second best quality of dying in the world because of its '[h]igh levels of public spending on healthcare services' and ' $[\mathrm{g}]$ enerous subsidies to reduce the financial burden of palliative care on patients. ${ }^{17}$ The problem here is not the veracity of these statements, but that dying is conceived of in economic terms and the question of choice is calculated on the basis of a cost-benefit analysis. Indeed, the costs of dying, as a matter of choice, are not simply a concern for the consumer patient but for governments themselves, for as The Economist extols, investment in community-based palliative care can offer savings in other health-related costs. ${ }^{18}$

Economic analysis on the manner of dying has been discursively framed since the twentieth century around the ideal of the consumer patient who has a choice about where, when and how they may die. The discourse of choice flows throughout debates about end-of-life care, from rightto-die activism to healthcare consumer advocacy, from public forums to parliamentary committees. When the Victorian Government asked the Legislative Council's Legal and Social Issues Committee, which recommended the enactment of a legislative framework for assisted dying in Victoria, to begin an inquiry into end-of-life care, it framed the

15 Hal Swerissen and Stephen Duckett, Dying Well (Grattan Institute Report No 2014-10, September 2014) 1,4 <https://grattan.edu.au/wp-content/uploads/2014/09/815-dying-well.pdf $>$.

16 Ibid 21. See further, Martina Orlovic, Joachim Marti and Elias Mossialos, 'Analysis of Endof-Life Care, Out-of-Pocket Spending, and Place of Death in 16 European Countries and Israel' (2017) 36(7) Health Affairs 1201; Mette Asbjoern Neergaard et al, 'What Socio-Economic Factors Determine Place of Death for People with Life-Limiting Illness? A Systematic Review and Appraisal of Methodological Rigour' (2019) 33(8) Palliative Medicine 900.

17 The Economist Intelligence Unit, 2015 Quality of Death Index: Ranking Palliative Care Across the World (Report, 2015) 7.

18 Ibid 8. See also, Stephen Duckett, 'Aligning Policy Objectives and Payment Design in Palliative Care' (2018) 17(42) BMC Palliative Care 1. In Canada, this has been taken further by medical practitioners who suggest that annual healthcare spending for patients nearing the end of their lives could be substantially reduced by 'between $\$ 34.7$ million and $\$ 138.8$ million' through the implementation of a medical assistance in dying regime. Though they are at pains to explain that they

are not suggesting medical assistance in dying as a measure to cut costs. At an individual level, neither patients nor physicians should consider costs when making the very personal decision to request, or provide, this intervention.

Aaron J Trachtenberg and Braden Manns, 'Cost Analysis of Medical Assistance in Dying in Canada' (2017) 189(3) Canadian Medical Association Journal E101, E101 and E104. 
discussion around the question of choice. ${ }^{19}$ In addition, when the then Minister for Health introduced in parliament the second reading speech of the Voluntary Assisted Dying Bill 2017 (Vic), the language of choice was deployed to frame the government's support of voluntary assisted dying. The Act would provide a highly regulated opportunity for eligible Victorians to choose the time, place and manner of one's death. Not only does this discourse misrecognise how dying is always already relational and contingent, ${ }^{20}$ but it underpins the extent to which dying as a matter of choice is governed through economic terms.

In the twenty-first century, neoliberal rationality has tended to redefine the question of choice as a problem of 'user experience' and, to this extent, the consumer patient has morphed into an 'end user' of healthcare. Portable's 2019 report on The Future of Death \& Ageing in Australia identifies a number of 'pain points' of the 'user experience' of dying and proposes changes to make it more 'user friendly'. ${ }^{21}$ The company writes that:

[e]veryone is an end user and we will likely experience the death and ageing of others before our own. Each and every one of us has an interest in making the experiences more positive and less frustrating. ${ }^{22}$

Portable's solution to this problem is the 'appification' of dying. The company has designed prototype apps for digitally storing advanced care directives, a virtual deck of cards for catalysing end-of-life conversations and social networks for gathering together dying patients, carers and death doulas. The appification of end-of-life care is designed, as Portable notes, to ' $[\mathrm{p}] \mathrm{ut}$ the user in the centre of products and services'. ${ }^{23}$

The substitution of the consumer with the discourse of the user and the appification of dying further extends techniques of economisation into end-of-life care. While Portable's report does not analyse the implementation of voluntary assisted dying in Victoria, in a 2019 blog

19 Department of Health and Human Services, Government of Victoria, Ministerial Advisory Panel on Voluntary Assisted Dying (Final Report, 31 July 2017).

20 Ari Gandsman, 'Paradox of Choice and the Illusion of Autonomy: The Construction of Ethical Subjects in Right-to-Die Activism' (2018) 42(5) Death Studies 329.

21 Portable, The Future of Death \& Ageing in Australia: A Portable R\&D Initiative (Report, 2019) 9

$<$ https://www.portable.com.au/reports/the-future-of-death-and-ageing>.

22 Ibid 10.

23 Ibid 94. 
post, it employs the term ' $U X$ ', which has become slang for user experience, to discuss the question of access to the administrative procedures of the scheme. Portable opines that

[i]t may be distasteful to evaluate ... VAD as 'consumer' experiences, but as the Government starts to take a humancentred, or customer-focussed approach to providing services, it's important to critique it. This service is likely going to be accessible mostly to those who can afford to think in terms of 'being consumers'. Those who, in a neoliberal economic sense, can participate, represent themselves in a complex system and have enough mobility to choose how they might like to die. ${ }^{24}$

The blog categorises voluntary assisted dying as a user experience to both identify its in-built 'pain points' (or what the government may call safeguards), but also to critique the neoliberal rationality that conditions the emergence of this discourse. Portable warns against the privatisation of end-of-life care in Australia, and yet when read together with its report on The Future of Death \& Ageing, the blog reveals an interest in how relations between the living, the dying and the state can be optimised and enhanced in the pursuit of an user-friendly experience of voluntary assisted dying. However, as the next section shows, the language of economisation already permeates the legislated regime for voluntary assisted dying. In other words, it is not surprising that a company such as Portable, which specialises in 'human-centred' or 'user experience' design, conceptualises medically supervised dying through discourses of economic rationality, because the dying themselves already participate as decision-makers in an economy of human capital.

\section{Dying as a matter of time}

In Files: Law and Media Technology, Cornelia Vismann argues that filing is integral to the institutionalisation of law. She writes that law is 'a repository of forms of authoritarian and administrative acts that assume concrete shape in files'. ${ }^{25}$ To put this differently, law and files are mutually constitutive. The former assumes its institutional form in the recording

24 'The UX of Voluntary Assisted Dying: Friction and Complexity as Safeguards', Portable (Blog Post) <https://www.portable.com.au/blog/the-ux-of-voluntary-assisted-dying>.

25 Cornelia Vismann, Files: Law and Media Technology, tr Geoffrey Winthrop-Young (Stanford University Press, 2008) xiii. 
of its proceedings, yet files acquire their materiality in the institutional practices of law. This is most evident in how a patient may access medically supervised assisted dying in Victoria. ${ }^{26}$ The administration of voluntary assisted dying requires that a patient prove that they have 'decision-making capacity', ${ }^{27}$ they have a serious and incurable disease, illness or medical condition, ${ }^{28}$ and that disease, illness or medical condition is causing intolerable suffering. ${ }^{29}$ The patient must first request from a doctor access to assisted dying, ${ }^{30}$ which formally commences the bureaucratic process, but they also must repeat that initial step if a doctor refuses. ${ }^{31}$ If the doctor accepts the request, the patient must then undergo an assessment by that doctor and if they are deemed eligible to be a decision-maker, the doctor must within seven days submit a report in Form 1 to the Voluntary Assisted Dying Review Board. ${ }^{32}$ The patient must then undergo a consulting assessment by a different doctor, which will result in the submission of another report in Form 1 to the Voluntary Assisted Dying Review Board. ${ }^{33}$ Following the second assessment, both doctors need to make a 'written declaration' in Form 3 on behalf of the decision-maker, requesting access to lawful assisted dying. ${ }^{34}$ The final request must then be made after the signing of the written declaration at least nine days after the first request was made. ${ }^{35}$

The administration of voluntary assisted dying undoubtedly assumes its legal form in an economy, a cascade of files, reports and forms. 'In our cultures "paper shuffling" is the source of an essential power', writes Bruno Latour, 'that constantly escapes attention since its materiality is ignored'. ${ }^{36}$

26 The administrative procedures are outlined in the Voluntary Assisted Dying Act 2017 (Vic) s 6. They involve the following steps: first request; first assessment; consulting assessment; written declaration; final request; contact person appointment; final review and permit application.

27 Voluntary Assisted Dying Act 2017 (Vic) s 9(1)(c).

28 Voluntary Assisted Dying Act 2017 (Vic) s 9(1)(d).

29 Voluntary Assisted Dying Act 2017 (Vic) s 9(1)(d)(iv).

30 Voluntary Assisted Dying Act 2017 (Vic) s 11 . This request can only be made to a 'registered medical practitioner' in person. The health practitioner must not initiate this discussion under section 8 . They have seven days to decide whether to accept or refuse the request.

31 Voluntary Assisted Dying Act 2017 (Vic) s 13. Medical practitioners can refuse to participate in the process because of a conscientious objection to voluntary assisted dying, because they are not able to perform duties under the Act or because they are not qualified to do so.

32 Voluntary Assisted Dying Act 2017 (Vic) ss 16-21. Under section 19, the first doctor must provide the following information to the patient: diagnosis and prognosis; end of life options; risks of assisted dying; the effects of assisted dying; and the right not to continue with assisted dying at any time.

33 Voluntary Assisted Dying Act 2017 (Vic) ss 22-30.

34 Voluntary Assisted Dying Act 2017 (Vic) ss 34-36.

35 Voluntary Assisted Dying Act 2017 (Vic) ss 37-38.

36 Bruno Latour, 'Drawing Things Together' in Michael Lynch and Steve Woolgar (eds), Representation in Scientific Practice (MIT Press, 1990) 55. 
The copious amounts of paperwork produced by the implementation of Voluntary Assisted Dying Act 2017 (Vic), coupled with the legislatively determined time delays between each step of the process, means not only that eligible decision-makers may die before a 'permit' is issued, but that the time of dying is figured in economic terms. This is most evident in the panoply of guidance manuals and instruction booklets for health services, medical practitioners and consumer patients, which fragment the administrative procedures, but also the experience of voluntary assisted dying, into discrete units of time that can be elongated or truncated. ${ }^{37}$

In Undoing the Demos, Brown develops a theory of neoliberalism as a 'governing rationality' that extends into all aspects of living: 'all spheres of existence are framed and measured by economic terms and metrics, even when those spheres are not directly monetized'. ${ }^{38}$ Brown argues that in the twenty-first century a condition of possibility of human life is a historically specific form of economic rationality, which extols, for example, human beings to optimise the economic value of time. Her book builds upon both Michel Callon's performative concept of economisation, which he utilises to describe 'behaviours, organizations, institutions and, more generally, the objects in a particular society ... as "economic", 39 and Michel Foucault's historical account of governmentality, or the transformations in the art of government, which he contends embedded the notion of the economy into the management of the population during the eighteenth century. ${ }^{40}$

If neoliberal rationality emerges in the twentieth century as a distinctive form of governance, it is due to the fact that it is both pervasive, yet disunified in constructing persons and states on the model of corporate firms and self-investing entrepreneurs competing against each other in an economy of human capital. Economisation is a model for the conduct of government, but also a model for the government of the self, where both

37 See for example, Department of Health and Human Services, Government of Victoria, Voluntary Assisted Dying: Information for People Considering Voluntary Assisted Dying (11 October 2019); Department of Health and Human Services, Government of Victoria, Voluntary Assisted Dying: Guidance for Health Practitioners (4 July 2019); Department of Health and Human Services, Government of Victoria, Voluntary Assisted Dying: Managing Access to Voluntary Assisted Dying in Health Services (18 April 2019).

38 Brown (n 11) 10.

39 Koray Çalışkan and Michel Callon, 'Economization, Part 1: Shifting Attention From the Economy Towards Processes of Economization' (2009) 38(3) Economy and Society 369, 370.

40 Michel Foucault, 'Governmentality' in Graham Burchell, Colin Gordon and Peter Miller (eds), The Foucault Effect: Studies in Governmentality (The University of Chicago Press, 1991). 
persons and states transform every aspect of society into a market and in this process, they themselves are transformed into market actors. The homo oeconomicus that Foucault introduces in his lectures on biopolitics becomes then for Brown a market actor that 'takes its shape [everywhere] as human capital seeking to strengthen its competitive positioning and appreciate its value, rather than as a figure of exchange or interests. ${ }^{41}$

The language of economisation suffuses relations between decisionmakers, medical practitioners and the state, cultivated in the implementation of a voluntary assisted dying regime. It manifests in the bureaucratic procedures for determining whether a person has 'decisionmaking capacity' and also in the organisation of a permit system created to govern access to voluntary assisted dying for eligible decision-makers. The remainder of this chapter explores how decision-makers participate in an economy of human capital and it concludes that this model for the conduct of government will lead to differential experiences of voluntary assisted dying, particularly for patients who struggle to comport to the norms of, but importantly demonstrate their performance of themselves as, homo oeconomicus, or as Brown puts it, 'comport themselves in ways that maximize their capital value in the present and enhance their future value'. ${ }^{42}$

Dorsett and McVeigh explain that the temporary legalisation of euthanasia in the Northern Territory in the 1990s required 'terminally ill people' to demonstrate that they have a capacity to petition a medical practitioner to access physician-assisted dying. They had to show that they 'possess a set of competencies in the management of one's affairs'. ${ }^{43}$ 'Decisionmaking capacity' is defined under section 4(1) of Voluntary Assisted Dying Act 2017 (Vic) as the ability to understand information about the administration of voluntary assisted dying, retain that information to the extent of making a decision, use or weigh that information in the process of making a decision and communicate that decision through speech, gestures or other means. While the standard of proof for determining whether a person has capacity lies outside the legislation, which means a subjective assessment is to be made by medical practitioners, the Act points out that they should not make assumptions about how a person may understand the administration and especially, the consequences of

\footnotetext{
41 Brown (n 11) 33.

42 Ibid 22.

43 Dorsett and McVeigh (n 10) 87.
} 
voluntary assisted dying - 'modified language, visual aids or any other means' may be required ${ }^{44}$ - and they should not make an assessment based on a person's appearance or opinions..$^{45}$ Doctors must take into account that 'practicable and appropriate support' should be given for someone to make a decision, such as the use of specific technology, extended time to understand and deliberate, allowing someone to assist with communicating a decision or using information or formats tailored to the particular needs of a person. ${ }^{46}$

Notwithstanding the attempts by lawmakers to curtail the subjectivity of the assessment process, what Dorsett and McVeigh wrote about the administration of euthanasia in the Northern Territory applies equally to the implementation of voluntary assisted dying in Victoria. The state may presume that a person has a capacity to make a decision, if they can demonstrate that they can manage their affairs, or rather, that they can participate in a cost-benefit analysis regarding their own death. What I am suggesting here is that the subjective assessment of decision-making capacity by a medical practitioner and its affirmation by government officers is inextricable from a neoliberal rationality that has subjugated, normalised and measured all spheres of life and death according to economic terms. The patient in this context can only acquire the status of a decision-maker by performing homo oeconomicus:

an intensely constructed and governed bit of human capital tasked with improving and leveraging its competitive positioning and with enhancing its (monetary and nonmonetary) portfolio value across all of its endeavors and venues. ${ }^{47}$

Whether this performance consists of theorising the economic consequences of the extension or reduction of one's life for oneself, another or the state, or conceptualising a prognosis in terms of time left to be maximised - that is, how can time be financialised for monetary or nonmonetary purposes - homo oeconomicus, as a performance and a status, increases the 'value' of the patient's life and death for the purposes of making an assessment on their competency. It may be strange to think of a person seeking access to voluntary assisted dying in relation to notions

44 Voluntary Assisted Dying Act 2017 (Vic) s 4(3).

45 Voluntary Assisted Dying Act 2017 (Vic) s 4(4)(c).

46 Voluntary Assisted Dying Act 2017 (Vic) s 4(4)(d).

47 Brown (n 11) 10. 
of economisation, value seeking and 'competitive positioning', but as I remarked in the previous section, neoliberal rationality has extended itself into all spheres of end-of-life care.

It could be noted further that doctors are assessing a patient's capacity through their own understanding and situatedness, which is determined by a constellation of power-knowledge relations, of what kind of human capital is required to understand and retain information, and deliberate and communicate a decision. Not only are the doctors fashioning themselves everywhere as homo oeconomicus - that is after all integral to their vocations - but they are assessing their patients' capacity to perform 'human capital' by reference to an economic rationality constituted as 'sophisticated common sense, a reality principle remaking institutions and human beings everywhere it settles, nestles, and gains affirmation'. ${ }^{48}$ This means that while patients may not be subject to overt discrimination by medical practitioners, which is explicitly prohibited by the Act, they will nonetheless be assessed through an epistemological framework inextricable from the governing rationality of homo oeconomicus.

The economisation of dying does not only appear in the form and content for determining whether a person has 'decision-making capacity'. It also manifests in the permit system created to govern access to voluntary assisted dying for the decision-maker who has successfully made a final request to the coordinating doctor. The doctor may subsequently apply under Voluntary Assisted Dying Act 2017 (Vic) for a self-administration permit, ${ }^{49}$ which authorises a doctor to prescribe and supply a 'voluntary assisted dying substance ${ }^{\prime 50}$ to be self-administered by the decision-maker, or a practitioner administration permit, ${ }^{51}$ which authorises a doctor to administer that substance themselves, particularly if the decision-maker is incapable of self-administration and requests the doctor to do so. These permits are crucial for understanding how time is economised by the Act, for the processing and issuing of permits is yet to be constrained within a specified limit. It can only be surmised that administrative time would

48 Ibid, 35.

49 Voluntary Assisted Dying Act 2017 (Vic) ss 45, 47.

50 The ingredients of the 'lethal' substance remain shrouded in secrecy. It is clear though that the substance is hand-delivered by hospital pharmacists and placed in a prescribed locked box that can only be accessed by eligible decision-makers. The pharmacists are also directed to retrieve and dispose any unused medications from the contact person of the deceased decision-maker. See further, Department of Health and Human Services, Government of Victoria, Voluntary Assisted Dying: Statewide Pharmacy Service FAQs (January 2019).

51 Voluntary Assisted Dying Act 2017 (Vic) ss 46, 48. 
be subject to 'economic policy', however much individual bureaucrats would like to issue permits as soon as possible, in the same way that a corporation dictates metrics for processing life insurance claims after the death of a spouse or a parent and while the bereaved find themselves in an economically vulnerable position. Yet this is not all that can be said about how the Act understands the timing of dying, for while there are also no time limits enshrined in the Act for the use of the permits, expiry dates can be embedded in the lethal substances themselves. These substances, which are administered by the government through contracts with pharmaceutical corporations, must be destroyed by the coordinating doctor or returned to the dispensing pharmacy if not used (promptly). ${ }^{52}$

Voluntary assisted dying creates a bureaucratic apparatus for lawfully hastening the death of a particular type of person who has 'decisionmaking capacity'. While it transforms the government of death in the twenty-first century, it is important not to see this as a liberatory moment, a radical break from a past that prohibited suicide, assisted suicide and medically supervised dying. This new technology for governing death sits among a repertoire of institutional practices that have sought to economise many aspects of dying. The risk of course of failing to inquire into how voluntary assisted dying fits into and further enhances, rather than breaks from, the economisation of life and death under neoliberalism, is that only those who can harness their capital to demonstrate that they can manage their own affairs, that they can perform the role of homo oeconomicus, even if that is geared towards gaining a nonmonetary legal status of 'decision-maker', will be able to access lawful means of medically supervised assisted dying. Indeed, the integration of the government of death with neoliberal rationality will augment socio-economic inequality in creating differential experiences of voluntary assisted dying. But even for those eligible decision-makers that gain access to the voluntary assisted

52 The disposing of a lethal substance of course requires additional paperwork: the completion of a disposal form and records of disposal or return: Voluntary Assisted Dying Act 2017 (Vic) ss 54-55, 57-63. It should be clear at this point that only those who can afford to wait for a permit to die may actually receive one. In the second report on the operations of the Act, the Voluntary Assisted Dying Review Board tabled that 19 people may have died during the application process from 'means other than voluntary assisted dying: Voluntary Assisted Dying Review Board, Safer Care Victoria, Report of Operations June to December 2019 (Report, 2020) 3. By the third report, this number may have increased substantially as more people applied to access voluntary assisted dying in Victoria: Voluntary Assisted Dying Review Board, Safer Care Victoria, Report of Operations January-June 2020 (Report No 3, 31 August 2020) 3. 
dying regime, their deaths do not lie outside the spheres of economics, for the very substances that cause their deaths are designed to make the most efficient and value-oriented use of everyone's time.

\section{Bibliography}

\section{A Articles/books/reports}

Bayatrizi, Zohreh, 'From Fate to Risk: The Quantification of Mortality in Early Modern Statistics' (2008) 25(1) Theory, Culture \& Society 121 doi.org/ $10.1177 / 0263276407085160$

Brown, Wendy, Undoing the Demos: Neoliberalism's Stealth Revolution (Zone Books, 1st ed, 2015)

Çalışkan, Koray and Michel Callon, 'Economization, Part 1: Shifting Attention from the Economy towards Processes of Economization' (2009) 38(3) Economy and Society 369 doi.org/10.1080/03085140903020580

Department of Health and Human Services, Government of Victoria, Ministerial Advisory Panel on Voluntary Assisted Dying (Final Report, 31 July 2017)

Department of Health and Human Services, Government of Victoria, Voluntary Assisted Dying: Guidance for Health Practitioners (4 July 2019)

Department of Health and Human Services, Government of Victoria, Voluntary Assisted Dying: Information for People Considering Voluntary Assisted Dying (11 October 2019)

Department of Health and Human Services, Government of Victoria, Voluntary Assisted Dying: Managing Access in Health Services (18 April 2019)

Department of Health and Human Services, Government of Victoria, Voluntary Assisted Dying: Statewide Pharmacy Service FAQs (January 2019)

Dorsett, Shaunnagh and Shaun McVeigh, Jurisdiction (Routledge, 2012)

Duckett, Stephen, 'Aligning Policy Objectives and Payment Design in Palliative Care' (2018) 17(42) BMC Palliative Care 1 doi.org/10.1186/s12904-018$0294-4$

The Economist Intelligence Unit, The 2015 Quality of Death Index Ranking Palliative Care Across the World (Report, October 2015) 
Foucault, Michel, The Birth of Biopolitics: Lectures at the Collège de France, 19781979, ed Arnold I Davidson, tr Graham Burchell (Picador, 2008)

Foucault, Michel, 'Governmentality' in Graham Burchell, Colin Gordon and Peter Miller (eds), The Foucault Effect: Studies in Governmentality (University of Chicago Press, 1991)

Foucault, Michel, The History of Sexuality, Volume 1: The Will to Knowledge, tr Robert Hurley (Penguin, 1998)

Foucault, Michel, 'The Political Technology of Individuals' in Luther H Martin, Huck Gutman and Patrick H Hutton (eds), Technologies of the Self: A Seminar with Michel Foucault (University of Massachusetts Press, 1st ed, 1988)

Gandsman, Ari, 'Paradox of Choice and the Illusion of Autonomy: The Construction of Ethical Subjects in Right-to-Die Activism' (2018) 42(5) Death Studies 329 doi.org/10.1080/07481187.2017.1396646

Latour, Bruno, 'Drawing Things Together' in Michael Lynch and Steve Woolgar (eds), Representation in Scientific Practice (MIT Press, 1990)

Lavi, Shai, 'How Dying Became a "Life Crisis"' (2008) 137(1) Dedalus 57 doi.org/ 10.1162/daed.2008.137.1.57

Lavi, Shai J, The Modern Art of Dying: A History of Euthanasia in the United States (Princeton University Press, 2005)

McVeigh, Shaun, 'Subjects of Jurisdiction: The Dying, Northern Territory, Australia, 1995-1997' in Shaun McVeigh (ed), Jurisprudence of Jurisdiction (Routledge, 2007) doi.org/10.4324/9780203945483-21

Neergaard, Mette Asbjoern et al, 'What Socio-Economic Factors Determine Place of Death for People with Life-Limiting Illness? A Systematic Review and Appraisal of Methodological Rigour' (2019) 33(8) Palliative Medicine 900 doi.org/10.1177/0269216319847089

Orlovic, Martina, Joachim Marti and Elias Mossialos, 'Analysis of End-of-Life Care, Out-of-Pocket Spending, and Place of Death in 16 European Countries and Israel' (2017) 36(7) Health Affairs 1201 doi.org/10.1377/hlthaff.2017.0166

Portable, The Future of Death \& Ageing in Australia: A Portable R\&D Initiative (Report, 2019)

Schadewaldt, Wolfgang, 'The Greek Concepts of "Nature" and "Technique" in Robert C Scharff and Val Pusek (eds), Philosophy of Technology: The Technological Condition: An Anthology (John Wiley \& Sons, Inc, 2nd ed, 2014) 
Swerissen, Hal and Stephen Duckett, Dying Well (Grattan Institute Report No 2014-10, September 2014) <https://grattan.edu.au/wp-content/uploads/ 2014/09/815-dying-well.pdf>

Trabsky, Marc, Law and the Dead: Technology, Relations and Institutions (Routledge, 2019)

Trachtenberg, Aaron J and Braden Manns, 'Cost Analysis of Medical Assistance in Dying in Canada' (2017) 189(3) Canadian Medical Association Journal E101 doi.org/10.1503/cmaj.160650

Vismann, Cornelia, Files: Law and Media Technology, tr Geoffrey WinthropYoung (Stanford University Press, 2008)

Voluntary Assisted Dying Review Board, Safer Care Victoria, Report of Operations January-June 2020 (Report No 3, 31 August 2020)

Voluntary Assisted Dying Review Board, Safer Care Victoria, Report of Operations June to December 2019 (Report, February 2020)

\section{B Legislation}

Voluntary Assisted Dying Act 2017 (Vic)

\section{Other}

'The UX of Voluntary Assisted Dying: Friction and Complexity as Safeguards', Portable (Blog Post) <https://www.portable.com.au/articles/the-ux-ofvoluntary-assisted-dying> 
This text is taken from Voluntary Assisted Dying: Law? Health? Justice?, edited by Daniel J Fleming and David J Carter, published 2022 by ANU Press, The Australian National University, Canberra, Australia.

doi.org/10.22459/VAD.2022.05 